\title{
PILOT SURVEY OF HAEMOGLOBIN AND PLASMA UREA CONCENTRATION IN A RANDOM SAMPLE OF ADULTS IN WALES 1965-66
}

\author{
BY
}

H. CAMPBELL*†, M.A., M.B., B.S., W. J. W. GREENE†, M.B., B.Ch., B.A.O., J. W. KEYSER*, M.Sc., Ph.D., F.R.I.C., M.Coll.Path., W. E. WATERS†, M.B., B.S., D.I.H., J. M. WEDDELL†, M.B., B.S., AND J. L. WITHEY*, M.R.C.S., M.R.C.P., M.Coll.Path.

From the Welsh National School of Medicine* and

The M.R.C. Epidemiological Research Unit $\dagger$, South Wales

In epidemiology it is essential that a definite physiological or pathological condition should be studied in a defined community. These requirements are sometimes difficult to meet because, although the population to be studied should be representative of a large community, the measurements involved usually require elaborate apparatus and clinical examination rooms which are not easily mobile.

Hitherto it has been the policy of the Epidemiological Research Unit (ERU) to study intensively a specific disease in selected but limited communities (Miall and Cochrane, 1956) as in the Rhondda Fach, Vale of Glamorgan, Staveley, Annandale, or Wensleydale, with the belief that although these communities are certain to experience unique genetic, cultural, economic, and climatic conditions yet a pattern will emerge of meaningful associations between pathological conditions and the environment. This policy has been a success in the past, but it has always been open to the criticism that the associations that were found were also unique to the selected population and could not be safely applied to the general population.

One way of confirming such epidemiological results is to repeat the investigations in a different community with a different environment, as was done for the surveys of blood pressure (Miall, 1960), bronchitis (Higgins, 1960), rheumatoid arthritis (Miall, Ball, and Kellgren, 1958), and anaemia (Kilpatrick, 1961), in which the studies in the mining valley of the Rhondda Fach were repeated in the agricultural community of the Vale of Glamorgan or elsewhere.

A second method is to investigate a condition in large communities of over 100,000 persons where a wider range of modern conditions of class, of industry and commerce, and of age and sex can be seen than in a small defined community; this method is being used in the Rhondda Borough and in Cardiff City.

A third method is to use the total population of a whole country and to allow every person within that country to have an equal chance of being drawn at random for inclusion in the study. To do this, however, implies that the population can be enumerated and the diagnostic techniques should be simple and mobile.

This paper outlines the methodology of such a study of haemoglobin and plasma urea concentrations in the adult population of Wales.

\section{Population}

There are various ways of enumerating and defining a population which do not necessarily give the same results:

(1) The census population as enumerated by the Registrar General remains confidential and cannot be made available to any other official or private source.

(2) A private census of a complete population would be possible. The ERU has completed several private censuses, but the cost for a large population would be prohibitive; we estimate about $£ 100$ per 1,000 households.

(3) It would be possible to approach the Local Executive Councils of the National Health Service for their permission to draw a random representative sample of persons for each local area from the N.H.S. lists. But the lists are confidential and the selection of the sample would have to be done by the staff 
of the Executive Councils themselves. Moreover, there would be conditions attached to the use of the names which might make it difficult to obtain an adequately high response rate from the sample.

(4) A sample for medical research could be drawn not of the population itself but of general practitioners in the N.H.S. and then a second-stage sample drawn from their practice list. This, however, would place a heavy load on those individual practitioners who happened to be selected and a single refusal by one doctor to take part would exclude from the sample a considerable percentage of individuals at one blow.

(5) An area sample could be drawn by selecting map references and enumerating all persons within a grid, as is the practice in ecological surveys. This technique has theoretical attractions and is used in the U.S.A., but in Wales where half the population is concentrated into Glamorgan and West Monmouthshire and the remaining 90 per cent. of the principality is sparsely inhabited this was felt to be an expensive method.

(6) Electoral rolls for the population may be used as a sampling frame; this has the disadvantages that only electors over the age of 21 are included in the study, non-electors and minors being excluded. In Wales, where the immigrant population is small, this was not considered an important restriction.

\section{Condition to be STUdied}

The primary object of the survey was to study the most effective way of approaching a random sample of the population. Members of the ERU staff have already completed several studies on anaemia (Kilpatrick, 1961; Kilpatrick and Hardisty, 1961; Elwood, 1964) on local populations, and these led us to believe that it would be valuable to ascertain the distribution of haemoglobin levels in a random sample of the total population of the country.

It was later decided that, when the haematological estimations had been made on these samples, the plasma could be used to measure the plasma urea, so this was also done.

\section{Epidemological Method}

If the survey were confined to adult persons, this would remove the main disadvantage arising from the use of electoral rolls, namely the absence of minors. It was also decided to exclude all those over 75 years of age as these persons would probably need a domiciliary visit by the general practitioner.

Medically qualified staff are required for taking venous blood as the medical supervision of field survey assistants in a domiciliary study would have been impossible. These doctors who would be taking the blood could be employed in several ways:

(1) General practitioners could be asked to cooperate and to take blood specimens from their own patients if these were included in the random sample.

(2) Doctors could be recruited locally on a sessional basis to visit the selected persons in their homes or in clinics.

(3) Doctors could be sent out from the ERU with or without a field assistant.

It was estimated that in a selected constituency, if 100 persons were chosen for inclusion in the random sample, the average number of the sample subjects who would be on a single doctor's list would be about five, but for individual practitioners this number might vary between one and nine.

It was decided to use a mixture of these methods? In the first place the general practitioner of the selected person would be asked to take a samplo of blood, but if this doctor did not wish to co? operate then the ERU would ask the Local Medical Officer of Health to take the blood either in a clinic or in the home of the person concerned. Finally, if both these methods failed to obtain a response, then a doctor from the Unit should visit the person and take blood in the home.

This technique had the serious disadvantage that it would not be possible to standardize a questionnaire when so many individuals were involved in the study. Hence the questions that could be asked of the subject had to be kept to the absolute minimum.

\section{SAMPLing Method}

Sampling was done by two stages. First the 36 Parliamentary Constituencies of Wales were placed in rank order according to density of electors. This ranking gave six roughly equal groups of approximately 300,000 electors, each consisting of six constituencies, and each group had a characteristic economic pattern. These are shown in Table I. The first group consists entirely of large urban centres, the second and third are mining and industrial towns, the fourth with the exception of West Flint consists of small mining and industrial towns, and 
TABLE I

PARLIAMENTARY CONSTITUENCY BY DENSITY OF ELECTORS

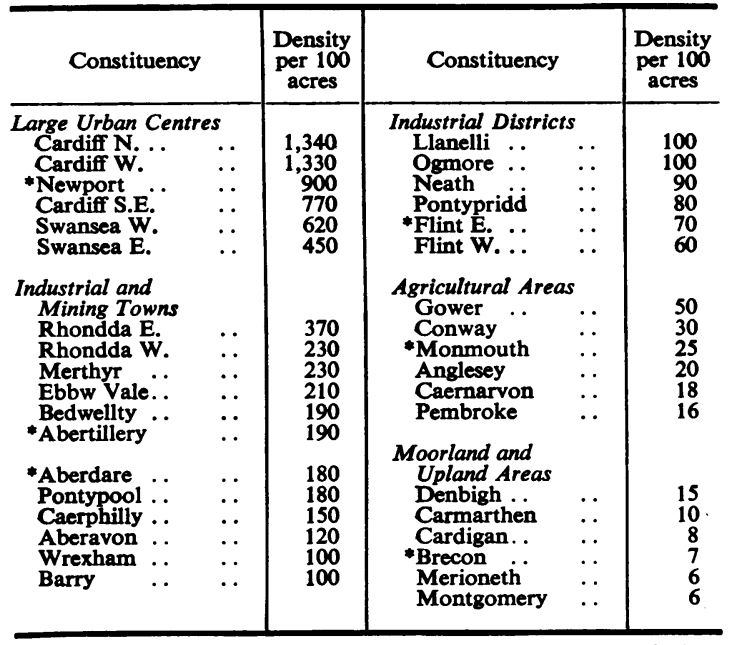

- Constituency selected at random within the groups of six constituencies.

fifth and sixth are agricultural or seaside residential areas.

One constituency was selected at random from each of these groups and the electoral rolls for these six areas were obtained. These rolls were published in February, 1965, but had been prepared in October, 1964, and hence they were at least one year out of date at the time the survey started. In the chosen constituencies the electoral rolls were then enumerated serially and 100 names drawn by using random numbers.

\section{Administrative Method}

A letter was sent to all selected subjects describing the anaemia survey and inviting them to co-operate. They were asked to give their age and the name of their general practitioner. Alternate letters made specific mention of a blood test or were non-specific on this point. It was hoped in this way to ascertain whether the mention of the blood test affected the response rate. If no reply was received to this letter, reminders, all of which mentioned the blood test, were sent 2 weeks later.

When a co-operative reply had been received and the subject was under 75 years of age, a letter was sent to the general practitioner asking for his help in taking a $2.5 \mathrm{ml}$. sample of venous blood. If the doctor agreed to this he was sent needles, syringes, and stamped addressed containers for the return of the blood samples and a letter was sent to the subject asking him to visit his doctor.
In a few cases in which the subject was cooperative but the doctor was unable to do this additional work, the Medical Officer of Health was asked to help by taking samples either in a public health clinic or in the patient's home.

The homes of nearly all the remaining subjects, including those who had not replied, those who had at first declined to co-operate, and those without a doctor, were visited by teams from the ERU.

\section{Analytical Methods}

A venous sample of blood was taken and $2.5 \mathrm{ml}$. put into a disposable plastic bottle containing sequestrene and carefully mixed. The bottle was placed in an aluminium alloy container which was then encased in a small pre-labelled sack and either posted to the Cardiff Royal Infirmary by the general practitioner or taken directly by car when the blood was drawn by a member of the Unit.

As soon as possible after receipt of the sample the haemoglobin concentration and packed cell volume were measured and a blood film was prepared. The remaining blood was then used to estimate the plasma urea concentration.

The haemoglobin concentration was estimated by two methods, one using an E.E.L. colorimeter, the other an AutoAnalyzer. The cyanmethhaemoglobin method was used in both types of apparatus and both instruments were standardized by a standard solution of cyanmethhaemoglobin controlled by the British Committee for standards in haematology, as supplied by the British Drug Houses.

Only the results obtained by the AutoAnalyzer are considered in this paper; a comparison between the two methods will be reported at a later date.

The packed cell volume was determined by the micro-haematocrit centrifuge (Hawksley), each determination being made in duplicate. The results of this determination are not recorded, because owing to the method of collection of the blood samples many specimens did not reach the laboratory until more than 24 hours after collection. 329 samples (72.8 per cent.) arrived within 24 hours, 82 (18.1 per cent.) within 48 hours, fifteen ( $3 \cdot 3$ per cent.) within 72 hours, three $(0.7$ per cent.) within 96 hours, two $(0.4$ per cent.) within 120 hours, two $(0.4$ per cent.) within 144 hours, and one $(0.2$ per cent.) within 168 hours. In eighteen $(4.0$ per cent.) the interval between collection and receipt was not known.

From previous experience it has been found that the packed cell volume is less reliable on specimens stored in sequestrene for more than 24 hours.

Cover-slip blood films were made and stained in the usual way and only examined if the haemoglobin 
and packed cell volume results were considered to warrant it.

Plasma urea was determined by the diacetyl monoxime method, using the AutoAnalyzer (Technician method N-la). Plasma values so obtained are, over the normal range, about $3 \mathrm{mg}$. per $100 \mathrm{ml}$. higher than those for whole blood. Standards and controls were run with every set of determinations.

Finally, a letter was sent to the general practitioners of all who had taken part in the survey advising them of the haemoglobin concentrations of their patients.

\section{RESPONSE RATES}

\section{RESULTS}

There were 600 names drawn for the sample, but for various technical reasons 82 (14 per cent.) were excluded from the survey; nine had died, forty had left the area, and 33 were over 75 years of age. From the 518 remaining subjects, 462 (89 per cent.) co-operated in the survey. Full details are shown in Table II.

TABLE II

RESPONSE RATE, BY SEX

\begin{tabular}{|c|c|c|c|c|c|}
\hline Sex & . & . & Male & Female & Persons \\
\hline \multicolumn{2}{|c|}{ Number in Sample } & $\ldots$ & 288 & 312 & 600 \\
\hline \multirow[t]{2}{*}{ Exclusions } & \multicolumn{2}{|c|}{$\begin{array}{l}\text { Over } 75 \\
\text { Left Area } \\
\text { Dead } . .\end{array}$} & $\begin{array}{r}7 \\
22 \\
6\end{array}$ & $\begin{array}{r}26 \\
18 \\
3\end{array}$ & $\begin{array}{r}33 \\
40 \\
9\end{array}$ \\
\hline & Total & $\ldots$ & 35 & 47 & 82 \\
\hline \multicolumn{2}{|c|}{ Effective Sample.. } & $\ldots$ & 253 & 265 & 518 \\
\hline Refusals .. & . & $\cdots$ & 19 & 37 & 56 \\
\hline Co-operators & \multicolumn{2}{|c|}{$\begin{array}{l}\text { Analysis by } \\
\text { Cardiff Roya } \\
\text { Infirmary } \\
\text { Analysis } \\
\text { elsewhere } \\
\begin{array}{c}\text { Specimen not } \\
\text { analysed }\end{array}\end{array}$} & $\begin{array}{r}228 \\
1 \\
5\end{array}$ & $\begin{array}{r}224 \\
2 \\
2\end{array}$ & $\begin{array}{r}452 \\
3 \\
7\end{array}$ \\
\hline \multicolumn{3}{|c|}{ Co-operators (per cent.) } & 92 & 85 & 89 \\
\hline
\end{tabular}

Men responded rather better than women (92 compared with 85 per cent.) and Table III shows that there were small variations between the constituencies, but with the numbers involved these differences were not statistically significant.

There were 300 preliminary letters which mentioned a blood test, and in reply to these 105 persons agreed within 14 days to co-operate; to the other 300 letters, which did not mention a test, only 94 co-operators replied within 14 days. This small difference does not suggest that people are deterred by the mention of a blood test but on the contrary that there may be some advantage in offering to do a blood test.

The methods by which the specimens were obtained are given in Table IV and V, which show $?$ that the ERU teams had to go out for at least half $N$ the bloods, and that in so doing they would fre- quently be passing the homes of those who had $\vec{A}$ co-operated with postal requests. There was, however, considerable variation in the help offered by the general practitioners in the various areas. In East Flint, Aberdare, and Brecon, only one-third of the specimens were collected by the ERU, whereas in Abertillery, Monmouth, and Newport the proportion was two-thirds. In only two areas $\vec{c}$

TABLE IV METHOD OF OBTAINING BLOOD SAMPLES,

\begin{tabular}{|c|c|c|c|c|c|}
\hline Sex & .. & .. & Male & Female & Persons \\
\hline \multirow[t]{2}{*}{ Method } & $\begin{array}{l}\text { Blood taken by } \\
\text { G.P. . . } \\
\text { Blood taken by } \\
\text { M.O.H. } \\
\text { Blood taken by } \\
\text { ERU ... }\end{array}$ & $\ldots$ & $\begin{array}{r}116 \\
6 \\
111\end{array}$ & $\begin{array}{r}91 \\
15 \\
119\end{array}$ & $\begin{array}{r}207 \\
21 \\
230\end{array}$ \\
\hline & Total & $\ldots$ & 233 & 225 & 458 \\
\hline
\end{tabular}

Note: This Table shows the method of obtaining the first specimen only. In a few cases these specimens clotted or were lost and repeated specimens were obtained by ERU.

TABLE III

RESPONSE RATE, BY CONSTITUENCY

\begin{tabular}{|c|c|c|c|c|c|c|c|c|c|c|}
\hline Constituency & $\cdots$ & $\cdots$ & $\cdots$ & $\cdots$ & East Flint & $\begin{array}{c}\text { Brecon } \\
\text { and Radnor }\end{array}$ & Abertillery & Aberdare & Newport & Monmouth \\
\hline Number in Sample & & $\cdots$ & $\cdots$ & $\cdots$ & 100 & 100 & 100 & 100 & 100 & 100 \\
\hline \multirow[t]{2}{*}{ Exclusions } & & $\begin{array}{l}75 \\
\text { t Area } \\
\text { ad }\end{array}$ & $\begin{array}{l}\cdots \\
\cdots \\
\end{array}$ & $\begin{array}{l}\cdots \\
\cdots \\
\end{array}$ & $\begin{array}{r}5 \\
2 \\
-\end{array}$ & $\begin{array}{l}4 \\
9 \\
2 \\
\end{array}$ & $\begin{array}{r}4 \\
8 \\
-\end{array}$ & $\begin{array}{l}8 \\
6 \\
3 \\
\end{array}$ & $\begin{array}{l}6 \\
5 \\
3 \\
\end{array}$ & $\begin{array}{r}6 \\
10 \\
1\end{array}$ \\
\hline & & & $\cdots$ & $\cdots$ & 7 & 15 & 12 & 17 & 14 & 17 \\
\hline Effective Sample & $\cdots$ & $\cdots$ & $\cdots$ & $\cdots$ & 93 & 85 & 88 & 83 & 86 & 83 \\
\hline Refusals $\quad$. & $\cdots$ & $\cdots$ & $\cdots$ & $\cdots$ & 8 & 5 & 11 & 10 & 9 & 13 \\
\hline Co-operators & $\cdots$ & $\cdots$ & $\cdots$ & $\cdots$ & 85 & 80 & 77 & 73 & 77 & 70 \\
\hline Response (per cen & t.) & $\cdots$ & $\cdots$ & . & 91 & 94 & 88 & 88 & 90 & 84 \\
\hline
\end{tabular}


did we actually ask for the co-operation of the medical officer of health and this was readily given.

TABLE V

METHOD OF OBTAINING BLOOD SAMPLES, BY CONSTITUENCY

\begin{tabular}{|c|c|c|c|}
\hline Constituency & $\begin{array}{c}\text { Bloods taken } \\
\text { by G.P. or } \\
\text { M.O.H. }\end{array}$ & $\begin{array}{l}\text { Bloods taken } \\
\text { by ERU }\end{array}$ & $\begin{array}{c}\text { Percentage of } \\
\text { Cases taken } \\
\text { by ERU }\end{array}$ \\
\hline $\begin{array}{lc}\text { East Flint. } & \text {.. } \\
\text { Brecon and Radnor } \\
\text { Abertillery } & \ldots \\
\text { Aberdare . . } & \text {. } \\
\text { Newport .. } & \text {. } \\
\text { Monmouth } & \text {. }\end{array}$ & $\begin{array}{l}54 \\
49 \\
29 \\
46 \\
25 \\
25\end{array}$ & $\begin{array}{l}30 \\
30 \\
48 \\
27 \\
52 \\
43\end{array}$ & $\begin{array}{l}36 \\
38 \\
62 \\
37 \\
67 \\
63\end{array}$ \\
\hline All Areas & 228 & 230 & 50 \\
\hline
\end{tabular}

The work done by the ERU in collecting these blood samples was considerable. The preparation of the initial letters to the subjects, the reminders and the letters to the general practitioners, the arrangements of the appointments with the cooperative patients, and dispatching the kits and checking their return occupied over 400 hours. Twenty different standard letters were duplicated, but nevertheless 200 individual letters had to be written either to the patients or to the doctors discussing personal matters raised by individuals.

When these methods had failed doctors from the ERU visited the subject personally, and they had good success in persuading those to co-operate who had not replied or had even refused initially to assist. A visit to their homes and the appearance of a sympathetic doctor worked wonders. The time thus taken up was considerable as the subjects were scattered widely over Wales and it was not easy to locate their addresses or to find them at home. The collection of the 230 blood specimens occupied 350 doctor hours, excluding time taken to travel to each constituency.

It seems that little saving in time or effort would be effected by asking the general practitioners to assist in taking blood, and this method of obtaining specimens places an onus not only on the practitioner but also on the patient who has to visit his doctor and wait his turn in the surgery.

\section{Haemoglobin Distribution}

There were 462 subjects who were able to cooperate with the study and provide a sample of blood. In seven of these cases the blood clotted or there were other technical failures and in three the blood was analysed at another laboratory. Thus $\mathbf{4 5 2}$ bloods were finally analysed by the laboratory at Cardiff Royal Infirmary (88 per cent. of the available population).

The distribution of the haemoglobin concentrations is shown in Table VI, and in Fig. 1 (overleaf).

TABLE VI

DISTRIBUTION OF HAEMOGLOBIN CONCENTRATION, BY SEX AND CONSTITUENCY

\begin{tabular}{|c|c|c|c|c|c|c|c|c|c|c|}
\hline \multirow[b]{2}{*}{ Sex } & \multirow{2}{*}{\multicolumn{3}{|c|}{$\underset{(\mathrm{g} . / 100 \mathrm{ml} .)}{\mathrm{Hb}}$}} & \multicolumn{6}{|c|}{ Constituency } & \multirow{2}{*}{ All Areas } \\
\hline & & & & East Flint & $\begin{array}{c}\text { Brecon } \\
\text { and Radnor }\end{array}$ & Abertillery & Aberdare & Newport & Monmouth & \\
\hline \multirow[t]{3}{*}{ Male } & $\begin{array}{r}9 \cdot 0-9.9 \\
10 \cdot 0-10.9 \\
11.0-11.9 \\
12.0-12.9 \\
13.0-13.9 \\
14 \cdot 0-14.9 \\
15.0-15.9 \\
16 \cdot 0-16.9 \\
17.0-17.9 \\
18.0-18.9\end{array}$ & $\begin{array}{l}\ldots \\
\because . \\
\because \\
\because \\
\because \\
\therefore \\
\therefore\end{array}$ & $\begin{array}{l}. \\
\because \\
\because \\
\because \\
\cdots \\
\cdots \\
\cdots\end{array}$ & $\begin{array}{r}\overline{-} \\
1 \\
5 \\
13 \\
11 \\
13 \\
1 \\
1\end{array}$ & $\begin{array}{l}= \\
= \\
11 \\
11 \\
10 \\
16 \\
2 \\
-\end{array}$ & $\begin{array}{r}\bar{Z} \\
\overline{3} \\
\frac{3}{5} \\
12 \\
8 \\
5 \\
1\end{array}$ & $\begin{array}{l}\frac{1}{二} \\
5 \\
14 \\
14 \\
8 \\
2 \\
-\end{array}$ & $\begin{array}{l}\text { 二 } \\
\overline{1} \\
3 \\
9 \\
8 \\
9 \\
2 \\
-\end{array}$ & $\begin{array}{l}= \\
\overline{1} \\
2 \\
11 \\
13 \\
6 \\
=\end{array}$ & $\begin{array}{r}1 \\
1 \\
5 \\
16 \\
63 \\
68 \\
60 \\
12 \\
2\end{array}$ \\
\hline & Total .. & .. & .. & 45 & 40 & 34 & 44 & 32 & 33 & 228 \\
\hline & $\begin{array}{l}\text { Mean } \\
\text { Standard d }\end{array}$ & riation & $\because$ & $\begin{array}{c}15 \cdot 3 \\
1 \cdot 25\end{array}$ & $\begin{array}{c}15.6 \\
0.95\end{array}$ & $\begin{array}{c}15 \cdot 7 \\
1.49\end{array}$ & $\begin{array}{c}15 \cdot 1 \\
1 \cdot 29\end{array}$ & $\begin{array}{c}15 \cdot 3 \\
1 \cdot 15\end{array}$ & $\begin{array}{c}15.1 \\
0.97\end{array}$ & $\begin{array}{c}15 \cdot 4 \\
1 \cdot 25\end{array}$ \\
\hline \multirow[t]{3}{*}{ Female } & 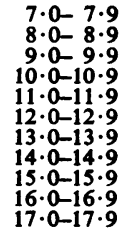 & $\begin{array}{l}. . \\
. . \\
. \\
\because \\
\therefore \\
\therefore \\
.\end{array}$ & $\begin{array}{l}. \\
\because \\
\because \\
\because \\
\because \\
\because \\
\because\end{array}$ & $\begin{array}{r}\frac{1}{1} \\
-\frac{2}{2} \\
7 \\
13 \\
11 \\
2 \\
2 \\
-\end{array}$ & $\begin{array}{r}1 \\
1 \\
2 \\
4 \\
13 \\
13 \\
3 \\
1 \\
-\end{array}$ & $\begin{array}{r}\frac{1}{1} \\
\frac{2}{2} \\
9 \\
17 \\
5 \\
2\end{array}$ & $\begin{array}{r}- \\
2 \\
1 \\
4 \\
12 \\
7 \\
\frac{2}{1}\end{array}$ & $\begin{array}{r}\text { 二 } \\
\overline{1} \\
5 \\
7 \\
13 \\
11 \\
6 \\
1 \\
1\end{array}$ & $\begin{array}{r}= \\
\overline{2} \\
2 \\
9 \\
10 \\
6 \\
5 \\
1 \\
-\end{array}$ & $\begin{array}{r}3 \\
3 \\
6 \\
12 \\
33 \\
70 \\
65 \\
23 \\
7 \\
2\end{array}$ \\
\hline & Total ... & .. & .. & 39 & 38 & 38 & 29 & 45 & 35 & 224 \\
\hline & $\begin{array}{l}\text { Mean } \\
\text { Standard d }\end{array}$ & riation & $\cdots$ & $\begin{array}{c}13.4 \\
1.66\end{array}$ & $\begin{array}{c}13 \cdot 5 \\
1 \cdot 50\end{array}$ & $\begin{array}{c}14 \cdot 0 \\
1 \cdot 74\end{array}$ & $\begin{array}{c}13 \cdot 5 \\
1 \cdot 58\end{array}$ & $\begin{array}{r}13 \cdot 6 \\
1.41\end{array}$ & $\begin{array}{c}13 \cdot 5 \\
1 \cdot 33\end{array}$ & $\begin{array}{c}13 \cdot 6 \\
1.55\end{array}$ \\
\hline
\end{tabular}




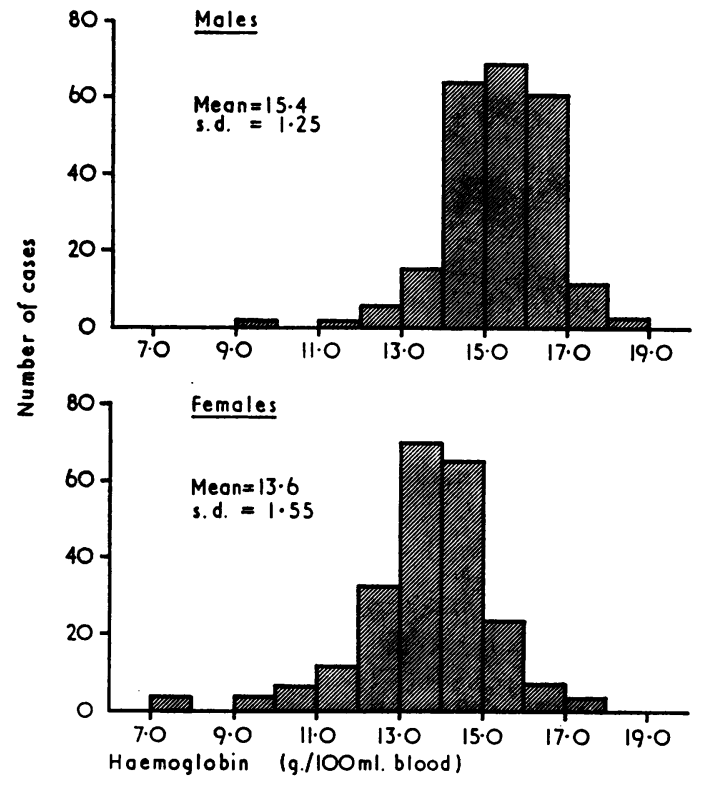

FiG. 1.-Haemoglobin (g./100 ml.) in males and females.

The men had a mean of $15.4 \mathrm{~g}$. per $100 \mathrm{ml}$. (standard deviation $\pm 1 \cdot 25$ ). There was no evidence of any significant differences between the survey constituencies, the range being from $15 \cdot 7 \mathrm{~g} . / 100 \mathrm{ml}$. in Abertillery to $15.1 \mathrm{~g} . / 100 \mathrm{ml}$. in Aberdare and Monmouth; the standard deviations in all areas were similar. There was no evidence of $\stackrel{\mathscr{O}}{\circ}$ bimodality and the frequency distribution seemed to be perfectly smooth from 18 to $11 \mathrm{~g} . / 100 \mathrm{ml}$. It is thus difficult to determine whether any particular level of haemoglobin was pathological or was a simple random deviation from normal. 10 per cent. had haemoglobin concentrations below $14 \mathrm{~g} . / 100 \mathrm{ml}$. and 1 per cent. below $12 \mathrm{~g}$. $/ 100 \mathrm{ml}$. There was one exceptional case of a man with a haemoglobin of $9 \mathrm{~g} . / 100 \mathrm{ml}$. who had no overt symptoms and is now being examined by his own doctor.

The women had a mean haemoglobin concentration of $13.6 \mathrm{~g} . / 100 \mathrm{ml}$. (standard deviation \pm 1.55 ). As with the men there was no evidence of significant variation between the constituencies, the highest $\bar{\varnothing}$ being Abertillery at $14 \mathrm{~g} . / 100 \mathrm{ml}$. and the lowest $\frac{\mathcal{S}}{\mathrm{S}}$ East Flint at $13.4 \mathrm{~g} . / 100 \mathrm{ml}$. The frequency distri- N bution was perfectly smooth from 17 to $9 \mathrm{~g} . / 100 \mathrm{ml}$. It was again difficult to determine a pathological $\triangleq$ level, but 11 per cent. had concentrations below $12 \mathrm{~g} . / 100 \mathrm{ml}$. and 3 per cent. below $10 \mathrm{~g} . / 100 \mathrm{ml}$. Three women with a haemoglobin below $8 \mathrm{~g} . /$ $100 \mathrm{ml}$. were reported to their own practitioners for further investigation.

The difference of $1.8 \mathrm{~g}$. between the means for men and women was highly significant $(P<\cdot 01 B \vec{\bullet}$ but it is also important to notice that the ratio 延 $\infty$ the variances was significant $(P<\cdot 05)$. Women ne only have lower haemoglobin concentrations tha men but also show more individual variation.

TABLE VII

DISTRIBUTION OF HAEMOGLOBIN CONCENTRATION, BY AGE AND SEX

\begin{tabular}{|c|c|c|c|c|c|c|c|c|c|}
\hline \multirow{2}{*}{ Sex } & \multirow{2}{*}{\multicolumn{3}{|c|}{$\underset{(\mathrm{g} . / 100 \mathrm{ml} .)}{\mathrm{Hb}}$}} & \multicolumn{6}{|c|}{ Age (yrs) } \\
\hline & & & & $21-34$ & $35-44$ & $45-54$ & $55-64$ & $65-74$ & All Ages \\
\hline \multirow[t]{3}{*}{ Male } & $\begin{array}{r}9 \cdot 0-9 \cdot 9 \\
10 \cdot 0-10 \cdot 9 \\
11 \cdot 0-11.9 \\
12 \cdot 0-12 \cdot 9 \\
13 \cdot 0-13.9 \\
14 \cdot 0-14.9 \\
15 \cdot 0-15 \cdot 9 \\
16.0-16.9 \\
17.0-17.9 \\
18 \cdot 0-18 \cdot 9\end{array}$ & $\begin{array}{l}. . \\
\because \\
\because \\
\because \\
\ddot{0} \\
\because\end{array}$ & 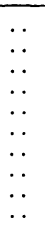 & $\begin{array}{c}\bar{Z} \\
\overline{7} \\
1 \\
5 \\
16 \\
20 \\
20 \\
3 \\
\text { N.A. }\end{array}$ & $\begin{array}{l} \\
\bar{Z} \\
5 \\
15 \\
18 \\
16 \\
3 \\
1\end{array}$ & $\begin{array}{l}\frac{1}{1} \\
3 \\
13 \\
15 \\
11 \\
2 \\
-\end{array}$ & $\begin{array}{r} \\
\overline{2} \\
2 \\
3 \\
15 \\
10 \\
7 \\
3 \\
1\end{array}$ & $\begin{array}{l}\frac{}{Z} \\
\frac{2}{4} \\
45 \\
6 \\
1 \\
-\end{array}$ & $\begin{array}{r}1 \\
1 \\
5 \\
16 \\
63 \\
68 \\
60 \\
12 \\
2\end{array}$ \\
\hline & Total ... & .. & .. & 65 & 58 & 46 & 41 & 18 & 228 \\
\hline & Mean .. & .. & .. & $15 \cdot 2$ & $15 \cdot 5$ & $15 \cdot 2$ & $15 \cdot 2$ & $15 \cdot 2$ & $15 \cdot 4$ \\
\hline \multirow[t]{3}{*}{ Female } & $\begin{array}{r}7 \cdot 0-7 \cdot 9 \\
8 \cdot 0-8 \cdot 9 \\
9 \cdot 0-9 \cdot 9 \\
10 \cdot 0-10 \cdot 9 \\
11 \cdot 0-11 \cdot 9 \\
12 \cdot 0-12 \cdot 9 \\
13 \cdot 0-13 \cdot 9 \\
14 \cdot 0-14 \cdot 9 \\
15 \cdot 0-15 \cdot 9 \\
16 \cdot 0-16.9 \\
17 \cdot 0-17 \cdot 9\end{array}$ & 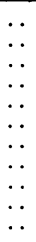 & 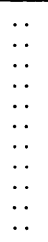 & $\begin{array}{r}1 \\
1 \\
4 \\
5 \\
9 \\
18 \\
18 \\
2 \\
=\end{array}$ & $\begin{array}{r}1 \\
1 \\
4 \\
13 \\
15 \\
8 \\
9 \\
2 \\
-\end{array}$ & $\begin{array}{l} \\
\overline{1} \\
1 \\
1 \\
6 \\
16 \\
18 \\
3 \\
1 \\
-\end{array}$ & $\begin{array}{r} \\
\\
\overline{2} \\
2 \\
3 \\
17 \\
12 \\
7 \\
2 \\
2\end{array}$ & $\begin{array}{l}\frac{1}{1} \\
1 \\
\frac{1}{2} \\
4 \\
9 \\
2 \\
2 \\
-\end{array}$ & $\begin{array}{r}3 \\
3 \\
6 \\
12 \\
33 \\
70 \\
65 \\
23 \\
7 \\
2\end{array}$ \\
\hline & Total ... & .. & .. & 58 & 53 & 46 & 45 & 22 & 224 \\
\hline & Mean .. & .. & .. & $13 \cdot 0$ & $13 \cdot 5$ & $13 \cdot 8$ & $14 \cdot 2$ & $13 \cdot 6$ & $13 \cdot 6$ \\
\hline
\end{tabular}




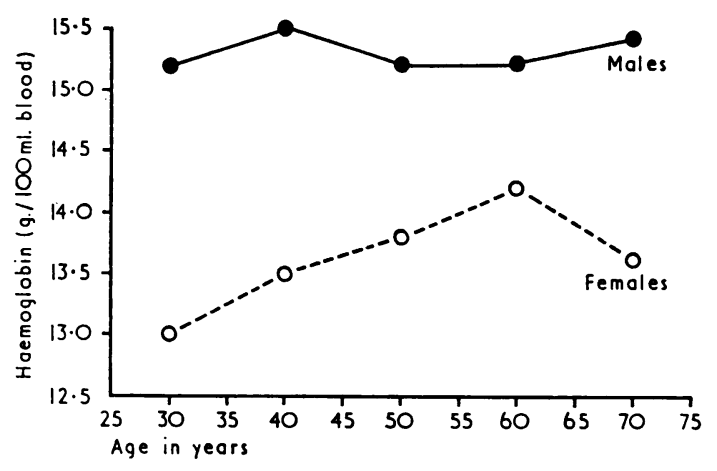

FIG. 2.-Haemoglobin concentration by age and sex.

The distribution of haemoglobin by age is shown in Table VII and Fig. 2. There was no evidence of any variation in the mean haemoglobin concentration for men associated with age up to 74 years. The women, however, show a very different picture. The mean haemoglobin concentration at ages 21 to 44 years is $13 \cdot 3 \mathrm{~g} . / 100 \mathrm{ml}$. whereas from 45 to 74 years it is $13.9 \mathrm{~g} . / 100 \mathrm{ml}$. This difference is certainly significant. The mean haemoglobin concentration for women increased steadily from 25 to 65 years and showed a fall only in the highest age group.

At ages 21 to 34 years the women had a mean haemoglobin concentration $2 \cdot 2 \mathrm{~g}$. below men of the same age, whereas at 55 to 64 years the sex difference had been reduced to $1 \mathrm{~g}$.

\section{Plasma Urea}

The distribution of plasma urea for each sex separately is given in Table VIII and Fig. 3, where it is seen that the mean for men is $31.8 \mathrm{mg} / 100 \mathrm{ml}$. whereas that for women is $28.7 \mathrm{mg} . / 100 \mathrm{ml}$. This

TABLE VIII

DISTRIBUTION OF PLASMA UREA CONCENTRATION, BY SEX

\begin{tabular}{|c|c|c|c|c|c|}
\hline \multirow{2}{*}{\multicolumn{3}{|c|}{$\begin{array}{l}\text { Plasma Urea } \\
\text { (mg./100 ml.) }\end{array}$}} & \multicolumn{3}{|c|}{ Sex } \\
\hline & & & Male & Female & Persons \\
\hline $\begin{array}{l}10-14 \\
15-19 \\
20-24 \\
25-29 \\
30-34 \\
35-39 \\
40-44 \\
45-49 \\
50-54 \\
55-59 \\
60-64 \\
65-69\end{array}$ & $\begin{array}{l}\ldots \\
\cdots \\
\cdots \\
\cdots \\
\cdots \\
\cdots \\
\cdots \\
\cdots\end{array}$ & $\begin{array}{l}\ldots \\
\cdots \\
\therefore \\
\cdots \\
\therefore \\
\therefore \\
\therefore \\
\therefore \\
\cdots\end{array}$ & $\begin{array}{r}-1 \\
25 \\
56 \\
74 \\
40 \\
9 \\
9 \\
2 \\
1 \\
-\end{array}$ & $\begin{array}{r}1 \\
18 \\
38 \\
76 \\
42 \\
25 \\
13 \\
1 \\
1 \\
- \\
1\end{array}$ & $\begin{array}{r}1 \\
19 \\
63 \\
132 \\
116 \\
65 \\
22 \\
10 \\
3 \\
1 \\
1\end{array}$ \\
\hline Total & . & . & 217 & 216 & 433 \\
\hline \multicolumn{3}{|c|}{$\begin{array}{l}\text { Mean } \\
\text { Standard deviation }\end{array}$} & $\begin{array}{r}31 \cdot 8 \\
6 \cdot 5\end{array}$ & $\begin{array}{r}28 \cdot 7 \\
7 \cdot 1\end{array}$ & $\begin{array}{r}30 \cdot 2 \\
6 \cdot 8\end{array}$ \\
\hline
\end{tabular}

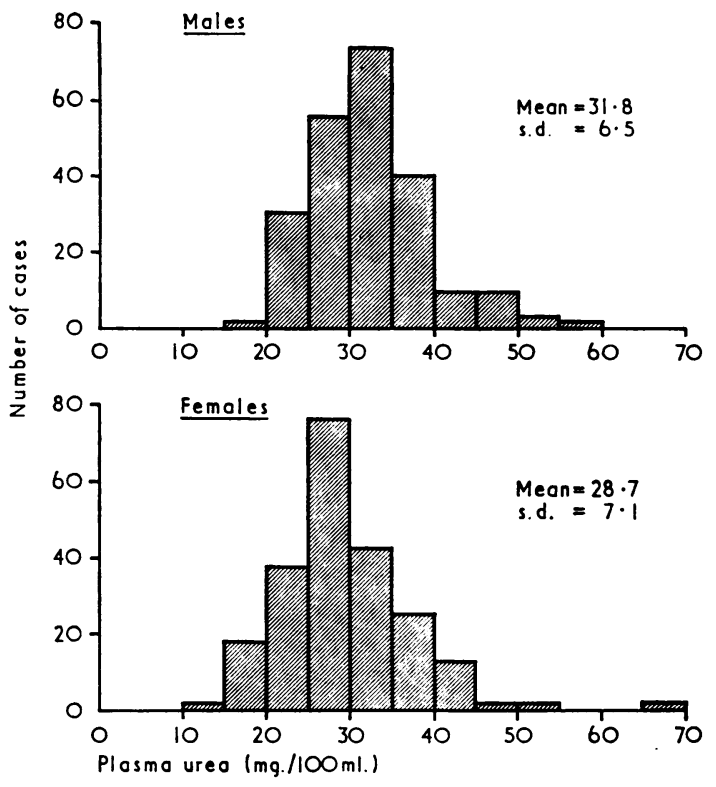

Fig. 3.-Plasma urea (mg./100 ml.) in males and females.

difference between the sexes is statistically significant. There is, however, no significance in the differences between the two standard deviations, 6.50 and $7.08 \mathrm{mg}$.

As with haemoglobin, the distribution is unimodal and varies from 14 to $69 \mathrm{mg} . / 100 \mathrm{ml}$; it may be observed that 9 per cent. of all cases have plasma ureas above $40 \mathrm{mg} . / 100 \mathrm{ml}$.

The variation between constituencies as shown in Table IX is not significant, but the sex difference is quite regular in all areas.

\section{TABLE IX}

MEAN PLASMA UREA CONCENTRATION (mg./100 ml.), BY CONSTITUENCY AND SEX

\begin{tabular}{|c|c|c|c|c|}
\hline \multirow{2}{*}{\multicolumn{3}{|c|}{ Constituency }} & \multicolumn{2}{|c|}{ Sex } \\
\hline & & & Male & Female \\
\hline $\begin{array}{l}\text { East Flint } \\
\text { Brecon .. } \\
\text { Abertillery } \\
\text { Aberdare } \\
\text { Newport } \\
\text { Monmouth }\end{array}$ & $\begin{array}{l}\ldots \\
\cdots \\
\cdots \\
\cdots \\
\cdots\end{array}$ & $\begin{array}{l}\cdots \\
\cdots \\
\cdots \\
\cdots\end{array}$ & $\begin{array}{l}31 \cdot 5 \\
33 \cdot 4 \\
32 \cdot 4 \\
29 \cdot 6 \\
31 \cdot 7 \\
32 \cdot 8\end{array}$ & $\begin{array}{l}28 \cdot 7 \\
29 \cdot 1 \\
27 \cdot 2 \\
26 \cdot 6 \\
30 \cdot 4 \\
29 \cdot 3\end{array}$ \\
\hline All Areas & $\ldots$ & $\ldots$ & $31 \cdot 8$ & $28 \cdot 7$ \\
\hline
\end{tabular}

The difference between ages shown in Table $\mathrm{X}$ and Fig. 4 (overleaf) is significant, and in both sexes the plasma urea concentration tends to rise with age. This rise is greater in women, where it is of the order of $1.5 \mathrm{mg}$. per decade of age. 
TABLE X

MEAN PLASMA UREA CONCENTRATION (mg./100 ml.), BY AGE AND SEX

\begin{tabular}{|c|c|c|c|c|c|}
\hline \multirow{2}{*}{\multicolumn{4}{|c|}{ Age (yrs) }} & \multicolumn{2}{|c|}{ Sex } \\
\hline & & & & \multirow{2}{*}{$\begin{array}{c}\text { Male } \\
30.4 \\
31 \cdot 5 \\
30.8 \\
34.9 \\
32.7\end{array}$} & \multirow{2}{*}{$\begin{array}{c}\text { Female } \\
25.6 \\
27.5 \\
30.0 \\
30.8 \\
32.9\end{array}$} \\
\hline $\begin{array}{l}21-34 \\
35-44 \\
45-54 \\
55-64 \\
65-74\end{array}$ & $\begin{array}{l}. \\
\therefore \\
\therefore \\
\therefore\end{array}$ & $\begin{array}{l}. \\
\because \\
\therefore \\
\therefore\end{array}$ & $\begin{array}{l}. \\
\cdots \\
\cdots \\
\ldots\end{array}$ & & \\
\hline All Age & s $\therefore$ & & $\ldots$ & $31 \cdot 8$ & $28 \cdot 7$ \\
\hline
\end{tabular}

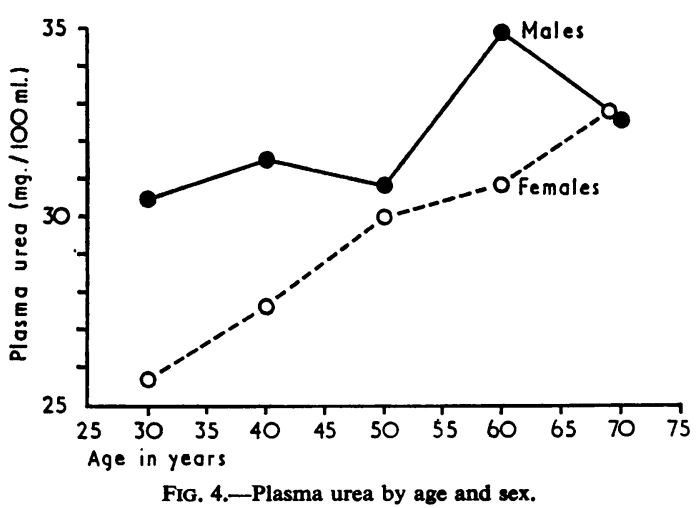

\section{Discussion}

\section{EPIDEMTOLOGICAL MethodS}

The primary purpose of this survey of Wales was to determine whether it was possible to study epidemiological variables in a random sample drawn from a total population and if so which were the best methods to use.

Wales is a particularly difficult country to choose for such a study. The total population is only $2 \cdot 7$ million spread over a large area which is broken up by a series of mountain ranges. Socially and culturally there are great variations between the regions; Glamorgan and Monmouth are almost entirely English-speaking, whereas Caernarvon, Anglesey, Merioneth, Cardigan, and Carmarthen have a stronger Welsh culture. Industrially there are wide differences, which cover the steel mills of Port Talbot, Llanelli, and Newport, the mining valleys of Glamorgan and West Monmouth, the lush farming regions of East Monmouth and the Vale of Glamorgan, the hill farms of Pembroke, Cardigan, and Carmarthen, the wild uplands of Caernarvon, Merioneth, and Montgomery, and the cities and ports of Newport, Cardiff, and Swansea. There is a wide range in the standard of medical services available to the population. In the mining valleys there is difficulty in maintaining an adequate number of general practitioners and junior hospital staff whereas in some other areas there are many highly-skilled doctors.

The difficulties are such that if an epidemiological technique works in Wales it should work in a more homogeneous region.

The basic sampling frame chosen for this work, the electoral roll, suffers from two serious defects in that it omits persons under the age of 21 and non-electors, amongst whom will be included peers, prisoners, and psychopaths, together with immigrants and those who have failed to register. Fortunately these categories are of less numerical importance in Wales than in other parts of the United Kingdom, and it is unlikely that this absence would seriously affect studies on the distribution of haemoglobin and plasma urea concentrations. The roll also quickly becomes out of date by death and removal. In the study forty out of 600 (7 per cent.) had moved out of the constituency before $\nexists$ they could be interviewed and nine had died. It is $ᄋ$ also a disadvantage that the roll does not give the occupation or the age of the individuals so that it cannot be used for stratified sampling by age or trade.

Other registers, however, are not at all suitable for random sampling. The N.H.S. Executive Counci lists are based upon doctors' records which may be out of date and which must be used confidentiallyg the National Insurance lists relate only to insurec persons; and in England and Wales there is not a complete regional register of all persons resident in an area. Hence the electoral roll, although it also rapidly becomes out of date, is probably the best instrument to use as a sampling frame, and this study confirms that it can be used for epidemiological purposes.

The study also allows us to make some recommendations as to the best methods of conducting such a survey in the future. It is essential that a unit carrying out a random sample survey should provide its own resources and be able to complete the task without calling in the help of the other branches of the health service. Although general practitioners, medical officers of health, and hospitals have been most generous and co-operative in offering to help with this work, the co-ordination of the results and the follow-up of the scattered sampling of units involved more work than would have been $N$ required by a single field team visiting each area and completing the whole task themselves.

It is also clear that a field team takes more time if the random sample is widely scattered over a $\stackrel{O}{C}$ whole constituency than if it is concentrated. $\mathbb{D}$ Brecon and Radnor for instance covers an area nearly $\mathbf{4 0}$ miles by $\mathbf{3 0}$ miles and many of the valleys 
have no cross-communication. Therefore, it would be a great economy to devise some method of clustering the sample in such a way that a number of subjects are drawn from the same hamlet or street. This would have the additional advantage that many persons would be able to offer guidance as to where to find others in the group. The size of such clusters should not be so big that they become complete sub-populations in themselves but they should be large enough to provide effective economy in the operation of the survey. An important consideration is whether the "variance" for certain measurable factors is different within different groups; if this is not the case then clustering is unlikely to bias the results.

The approach to the sample population should be made by the epidemiological team directly. It would be useful to send one letter to each person telling him that a survey is being organized and that a doctor will visit him. This letter should serve only as an introduction to guarantee the bona fides of the epidemiologist when he calls, and should not ask the recipient to undertake any positive action to co-operate with the survey until this call is received.

The visit should soon follow the letter, preferably within a week or so, in order to make maximum use of the good will that is generated when an individual is selected at random to take part in a survey. It might be an economy if the epidemiologist were to be preceded briefly by a home visitor who would locate the address and try to ensure that the subject would be at home and, if not, to make some convenient arrangement to contact him later.

If all the sample were to be seen by a small team of skilled epidemiologists, it would be possible to carry out a simple clinical examination in the home, to ask detailed questions concerning environment or aetiology, and even to collect blood, faeces, urine, or sputum for pathological examination. If the sample was adequately concentrated, it might be economical to establish a centre in a Local Authority Health Clinic for a few days and bring the sample population to the centre.

Using these techniques, there seems to be every prospect that a random sample of electoral rolls of Wales should provide an adequate population for a detailed epidemiological study.

\section{SUMmaRY}

(1) A survey of 600 persons drawn at random from the electoral rolls of Wales has been completed. Of the original 600,518 (86 per cent.) were still alive and resident in the area and were under the age of 75 at the time of the survey. Of this 518,462 (89 per cent.) co-operated in the study.

(2) A venous blood specimen was collected from 458 persons, 207 being collected by general practitioners, 21 by public health doctors, and 230 by epidemiologists from the ERU (Cardiff). From these specimens 452 were examined in the Cardiff Royal Infirmary.

(3) The mean haemoglobin concentration of the men was $15.4 \mathrm{~g} . / 100 \mathrm{ml}$. \pm 1.25 and of the women $13.6 \mathrm{~g} . / 100 \mathrm{ml} . \pm 1 \cdot 55$, a significant difference.

(4) The mean haemoglobin concentration of women aged 21 to 44 years was $13.3 \mathrm{~g} . / 100 \mathrm{ml}$. and of those aged 45 to 74 years $13.9 \mathrm{~g}$. This difference is significant.

(5) The mean plasma urea concentration was $31.8 \mathrm{mg} . / 100 \mathrm{ml} . \pm 6.5$ for men and $28.7 \mathrm{mg}$./ $100 \mathrm{ml}$. $\pm 7 \cdot 1$ for women, a significant difference.

(6) The conclusion is reached that, if a random sample of a total population is drawn from electoral rolls, it is possible to use this sample for an epidemiological study, but it is essential to rely upon a field survey team organized by the research unit for detailed medical work.

Our thanks are due to the general practitioners, Medical Officers of Health, laboratory staff, and all who gave able statistical and clerical assistance; but above all to those men and women chosen to take part in the survey without whose willing co-operation it would not have been possible to bring the work to a successful conclusion.

\section{REFERENCES}

Elwood, P. C. (1964). Brit. J. prev. soc. Med., 18, 81. Higgins, I. T. T. (1960). In "Industrial Pulmonary Diseases: a Symposium held at the Postgraduate Medical School of London, September, 1957, and March, 1958', ed. E. J. King and C. M. Fletcher, p. 195.

Kilpatrick, G. S. (1961). Brit. med. J., 2, 1736.

- and Hardisty, R. M. (1961). Ibid., 1, 778.

Miall, W. E. (1960). "Proceedings of Joint W.H.O.

Czechoslovak Cardiological Society", p. 88. State Publishing House, Prague.

- Ball, J., and Kellgren, J. H. (1958). Ann. rheum. Dis., 17, 263.

and Cochrane, A. L. (1956). Med. Wld, 85, 521. 